\title{
My Two-Timing Love for Two Languages \\ Or: My Practice of Translation
}

\section{Marne Killates}

Unyon ng mga Manunulat sa Pilipinas (UMPIL)

\section{Abstract}

A kind of creative writing which is often overlooked is literary translation. Though translation might be a self-evident activity requiring little reflection given the need to communicate between cultures, there seems to be a lacuna between translation theory and praxis in this realm in which the literal and the literary often blur, at least from the Philippine perspective. It is in this light that I share my ideas both as a translator and a poet in this essay, in which I reflect on the practice of translation and the experience of editing a translation of a play written by the highly esteemed creative writer, stage director, translator, actor, and National Artist, Rolando S. Tinio. Originally written in Tagalog, May Katwiran ang Katwiran, had been translated into English for a stage production with a foreign audience by the talented stage director, actor, scholar, and translator, Ricardo Abad, who had collaborated with a team on the initial English translation. With the title Reason Has Its Reasons, the work was edited like polishing a gem, as may be gleaned from the edited version that follows this essay which became the occasion for this reflection.

\section{Keywords}

Translation, Poetry, Writing Workshops, Translation Theory, Philippine Theater 
Asked often about my "process" of translation as a longtime translator mainly of poetry, but later also of prose; and mainly of literary translation but more frequently now of technical translation (I have been requested to translate into English or Filipino senate and congressional bills, resolutions and position papers), I have been quite hesitant to explain even to myself what this "process" is or might be. I thought it was enough that I was in the praxis and was not obliged to talk about the theory.

But I guess one can never really avoid these things-an academic friend reminded me that even the most hesitant, informal, but obliged explanation was a theory in itself-since I have been requested to share my experience in various literary and translation workshops. And, in fact, let me recall now a recent engagement: I have been asked to actually teach translation to senior high school students as part of their creative writing course at the Philippine High School for the Arts. (The students were actually two in number, one for each semester, as there were dwindling enrollees in creative writing compared to the performing arts, such that after two semesters the attrition had taken its toll with zero enrollees. Since I actually found the one-on-one classes quite exhilarating and I hope my two students did as well, the eventual absence of students put a stop to my more or less relaxing Monday afternoons in Makiling.)

Thus I found myself scrambling to read up on what I was just actually doing, to explain myself to me, and to my student. I found some friendly, practical descriptions from fellow poet practitioners-Norman Thomas di Giovanni, Ben Belitt, Nathaniel Tarn, and Alastair Reed, to name a few-but also the critical theorists like Walter Benjamin, apart the translated poets themselves like Borges when he was meditating on the incarnations and mutations of his poetry in translation.

Recalling my "career" of translation, the first "hint of fate" that I was going into this direction apart from writing my own poetry was that when I submitted my first poems in Tagalog to the GAT (Galian sa Arte at Tula) workshop in early 1988, Rio Alma's first remark was that they sounded like translations. Of course they were because they were originally written in English (after college I quite seriously took up writing poetry with English 
as my writing language). I wanted so much to write in Filipino but my "translations" wouldn't do. To be brief, the twists of fate were that I became the unofficial translator of GAT poets who were published in international anthologies, one who attended the Iowa Writers Workshop, and the GAT poet-singers who went into international concert tours (e.g., Heber Bartolome, Jess Santiago, and later friends like Pendong Aban of Grupong Pendong and the late Susan Fernandez) who needed translations of their songs for their program notes.

The feedback was encouraging when they returned-the translations were well appreciated and they kept being asked who their translator was. So the requests became more frequent and my next and first major translation assignment was to edit and translate, together with Mike L. Bigornia and Alfredo Navarro Salanga (both late and much lamented and missed) Rio Alma's first bilingual Selected Poems. And so I went into a parallel "career" of literary translation from Filipino into English while I attended the UP National Writers Workshop in 2004 as a writer in English. The workshop was experimental as it involved only one genre, poetry.

And so goes my little back story of how I came into literary translation. Now I came to reflecting on this as I finished helping edit and hopefully enhance an existing translation of Rolando Tinio's May Katuwiran ang Katuwiran which can be found after this essay. This, as I completed the 40th chapter of the 45-chapter novel, Ilaw sa Hilaga by Lazaro Francisco. So what have I learned so far as my work of translation literally ran parallel to my own work of poetry over more than three decades? Quite a few, actually.

Languages have different habits, different ways of creating meaning. And this is most pronounced between two languages from much disparate and different language families, such as the Germanic, Anglo-Saxon English, which came to us by way of colonization from the opposite side of the world, and Tagalog (the basis of Filipino, the national language), which is part of the huge Austronesian family whose speakers populate the territory stretching from Madagscar at the coast of Africa to Polynnesia in the Pacific. (Languages of the same family, and much more in the "cousin" or "filial" rela- 
tionship like Filipino native languages, have all the similarities you can think of, not really much difference/s.)

So translating between languages of such disparate families as English and Filipino, is really no easy task unless you love both languages. It is a task like transplanting meaning between two soils of different islands separated by oceans. It is an acrobatic act of close reading, deep understanding, and necessitating much manipulation and maneuver to render, especially literary works, in the literal, idiomatic, figurative, symbolic, emblematic, and metaphorical modes of the target language. Indeed, it is an act of love for both languages because the translator must intimately know either and both the source and the target language.

There is something perfidious about it, the act of translation is both artful and manipulative, but at the same time authentic and other-seeking. As the Italian adage so ambivalently states, "Traduttore, tradittore" (translator, traitor), translation betrays the meaning of the source language only to reveal it and generate understading and ultimately, appreciation. That is why there is really no accurate or perfect translation because there are many new ways of transplanting meaning as there are translators, from different places and lexicons, from different times (the Bible is translated continually, there are newer and newer translation editions of the Iliad and the Odyssey, there are a variety of ways of rendering idiomatic phrases in a different language and culture that constructs idioms differently, and there are numerous and endless amusing examples of untranslatable words).

Translation is the imperfect art, says Umberto Eco, but it is also the independent afterlife of a work of language, according to Walter Benjamin. In the relatively new field of Translation Studies, one of its advocates, our one-time conference speaker Lawrence Venuti, describes translation as both a process of "domestication" and "foreignization." The translating or target language "domesticates" the source language by minimizing its strangeness through a transparent and fluent style; it "naturalizes" the source language and the process is sense-for-sense, free, and consists of dynamic equivalents (Venuti). "Foreignization" seeks to preserve the original cultural context in 
terms of setting, names, and values literal, faithful, and formal equivalents and is often alienating (Outi Paloposki).

In my own estimation, the foregoing styles or methods of translation overlap and combine in practice depending not on the translator's preferences but on the necessities and ultimate literary goals and context. In my own case as a practicing translator, this becomes a "two-timing" love for my two writing languages, English and Filipino as I intimately know them. Rendering them intelligible to each other (or to their speakers and readers) is the only motivation for me to translate what I consider to be the best literary works, the supreme exemplars in the use of both languages or either language.

In another context, I am a victim as much of the English hegemony and American colonization when I love Robert Frost or T.S. Eliot or W.H. Auden or Seamus Heaney or W.B. Yeats. Just as I am impelled by my own Filipino-ness when I insist on the importance of a national language and express that love by translating into English-the language that has become my writing and creative language-the exemplars of our language, from Francisco Balagtas and Emilio Jacinto to Ildefonso Santos, A.G. Abadilla and Lazaro Francisco, and Rio Alma, Rogelio Mangahas, Lamberto Antonio, Ruth Elynia Mabanglo and numerous others of my contemporaries writing in the national language.

It is the same reason I admire our "regional" (for want of a better term) writers who persist in writing in their own language and in building their own bodies of literature (or works in the other areas or larang of knowledge), while acknowledging the need for Filipino because there is a Filipino nation being built out there. Many of these older and younger writers are bilingual and trilingual right at the start of their writing vocations, and have no compunctions about it. They are simply Filipino writers practicing out of a multicultural and multilingual nation. That is what we are, where we are now, more or less, as I estimate it in the development of the national language and in our engagements with our second "official" language.

And that is why, in the end, as I seek to explain myself to myself in my literary work, I find that I translate because I desire to partake in this engage- 
ment of languages, in the act of transplanting, cultvating, and resurrecting meaning in and among the archipelagos of culture, as it were, and across the gulf of relative ignorance and non-understanding.

Makati South Hills

Parañaque 


\section{Reason Has Its Reasons}

English translation of Rolando S. Tinio's "May Katwiran ang Katwiran” by Ricardo Abad, Cholo Ledesma, and Gabo Tolentino for the 11th Asia-Pacific Festival of Theater Schools

September 2018, Yogyakarta, Indonesia

\section{Prologue}

Scene: In some province at the present time

\section{Opening Song}

Look, observe, reflect

Consider carefully

The course of a life

You already know.

Each of the characters

Play a role

In a society

That no one can refuse.

When conflicts arise

Don't take it personally

It's class and point of view

That go toe-to-toe.

Look, observe, reflect

Consider carefully

Does it make sense at all

Does reason have a reason at all 
ONE ACTOR: In this play, we will not attempt to move your heart. Rather, we ask that you exercise your critical faculties. We'd like you to take a second look, so to speak, about the way certain people reason out their beliefs, their takenfor-granted, common sense understanding of their world. Do not simply agree to what the characters are saying, and say "Oh well, that's life." Rather, ask: "Should it be that way?" So scrutinize what they are saying, and assess if their reasons are reasonable at all. And reflect on your own experience.

Don't ever assume

That the life you have

You cannot avoid

And you have to accept it all

Do consider carefully

If what you consider

By your own judgment

Is reasonable at all

Imagine that life

Can be changed

If there's something wrong

Set it right, my friend.

Look, observe, reflect

Consider carefully

Is the reason you hold on to

The reason of a fool? 
Scene One

The Agreement

SEÑOR/HACIENDERO/LANDLORD

I need somebody who I can trust to bring me to the plain [pasture/pasture lands] on the other side of the mountain. Can you recommend anybody?

KASAMA/FARMER/TENANT/SERF/PEON/WORKER

You can trust me, sir. I'll be ready in a week.

SEÑOR I'll be delayed if I have to wait a week.

KASAMA If I rush my work in the field, or if I'm lucky enough to find a nephew or cousin who can take my place, I can go with you in three days.

SEÑOR Don't you understand that I'm in a hurry? I cannot waste a day, not even half a day.

KASAMA Sir, my father and brother need my help in farming across the cliff. I prepare them food and bring them home at noon. I plough the fields before I go home to prepare dinner.

SEÑOR If I offer you five pesos, can you find a replacement in five minutes?

KASAMA Everyone here is (busy) sowing. My cousins and nephews are in the town center. Maybe if it were August or September...

SEÑOR Will fifty pesos solve your problem?

KASAMA I'm not asking you to raise the price, sir.

SEÑOR Okay, five hundred. I won't go higher! 
KASAMA Five hundred...that's a lot of money, sir, but you don't have to. You-your father, your clan-we owe you our lives. It's an honor to help you as much we can. But unfortunately-

SEÑOR I mean, look-and it's a good thing you know who I amwe'll understand each other fine. I'll test you. Ready?

KASAMA Yes, sir.

SEÑOR Would you be able to live, to make a living, if you didn't work in our lands?

KASAMA No, sir.

SEÑOR Are we obliged to support you?

KASAMA [after thinking hard] No, sir. I think.

SEÑOR You think? Can you be sure of your answer? I think it's hard if you just think and think.

KASAMA Eh...

SEÑOR Let me help you. It is not actually our responsibility to support you-or anyone who lives here with you. Correct?

KASAMA That's correct, sir.

SEÑOR Okay, now... Do we treat you well?

KASAMA Oh, very well, sir!

SEÑOR There is nothing wrong with the way we treat you?

KASAMA None at all, sir!

SEÑOR Really?

KASAMA I swear, sir. 
SEÑOR Okay, I believe you... Now, understand this. If not, you might expose your stupidity. This is the question. If I ever struggle-and remember this rarely happens-if I ever run out of money, and you are the only person I can ask for help-but because of whatever reasons and excuses that may be important to you, but obviously don't mean anything to me-because of these excuses, you cannot help me-what do you think will happen?

KASAMA [smiles, but doesn't answer]

SEÑOR Why aren't you answering me?

KASAMA Sir, I'm confused with your question-it's so long. Can you repeat it, sir?

SEÑOR

Aba, of course not! It's your responsibility to listen to what you're asked. If you had a problem with the question, you should have said it earlier. It's too late now! The only thing you can do is to think and to pray that you'll somehow be able to answer, whether or not you understood the question.

In this world

There are two kinds of people

Those who question

and those who answer

Who of these will falter and break?

If it is the poor who ask

It is harder to ask the question

You must ask and be exact

But to answer you might mess up 
So never complain

If it's your turn to answer

Someone must always answer

Or we'll be bored waiting

Unlucky you, boy, what a mess

But you've no choice but to answer

KASAMA Ah, I know what you mean now, sir! If I cannot help you in your struggle, by all means, punish us!

SEÑR Oh?

KASAMA You can tell your farmhands not to give us anything to sow.

SEÑOR Really?

KASAMA You can take our carabao to make up for our debt that is long overdue.

SEÑOR What else?

KASAMA Is there anything else?

SEÑOR You're forgetting one very important thing.

KASAMA [after thinking hard] You can kick us out of your land!

SEÑR Very good! Siyento por siyento.

KASAMA Just one thing, sir. May I know why you're in a hurry? It will help me weigh things out.

SEÑOR Unfortunately, I've told you everything I can tell you.

KASAMA [after thinking] If that's the case, sir, I cannot do anything but go with you right now. I will just prepare. One moment, sir. [exit] 
[to the audience] I knew that's how our conversation would turn out. I just made it longer so that he won't complain that he wasn't given enough time to make up his own mind. But I have him by the neck, because I am Totoy del Prado y Ejercito, the son of a landlord from the Spanish royal bloodline.

My father sent me here to escape...because I killed some woman. [She was married but separated and she wanted me to marry her.] Now, a helicopter is coming to get me on the other side of our mountain, there. I will be brought to our island somewhere, where I will be transferred to our airplane that will bring me to our hotel in South America. Of course, I did not reveal this to the person I was just talking to, because I'm sure he will take advantage of me and my status, and find out about the one hundred thousand dollars I've hidden here.

Of course, when the helicopter gets here-and so that it doesn't get complicated-we'll get rid of him. Here is the scenario...I'll let him on the helicopter and drop him head first into the Pacific. If he dies, just think about the suffering he won't have to go through anymore. If he lives, then it's a divine miracle that even I cannot claim.

Be kind and be good

To whom you owe

So you won't capsize

When it's time to pay

You must know

There is no escape

You'll be finished

If you resist 
KASAMA Let's go, sir.

SEÑOR Why do you have a bolo?

KASAMA We might run into some snakes.

Scene Two

We Must Cross the Lake

KASAMA We'll save a lot of time if we can cross this lake instead of walking around it-we'll have to walk ten kilometers.

SEÑOR I'm tired. Go build a raft.

KASAMA We don't have supplies. I only brought this bolo, it's not even sharpened. We were in a hurry, I wasn't able to prepare.

SEÑOR There are lots of bamboo and vines out there. Find a way.

KASAMA It might get dark. It might take us longer.

SEÑOR You can build the raft in two hours, if you use your brain. Put it in your mind that I have a desperate need! If I don't make it to the other side of the mountain on time, my life might be in danger.

KASAMA We'll find a way, sir! 
Scene Three

The Raft Has a Deadline

SEÑOR Sun is going down, you're not yet done chopping wood?

KASAMA How, sir? I had to get some vines. I climbed high trees. There were three snakes that almost bit my leg-I killed them one by one.

SEÑOR I'll time you. I'll give you...let's see...exactly one hour to chop wood...and one more hour...no...half an hour...to tie them together.

KASAMA Sir, I think three hours is too little even just for gathering wood. We need to choose the right wood, older wood. And we'd be lucky to build the raft in two hours. We cannot rush it, sir-waves are strong at night, it might break.

SEÑOR One hour for the wood, half an hour to build the raft.

KASAMA Sir, I'm alone and the blade isn't sharp.

SEÑOR It isn't the blade that's not sharp. But, okay, I can be reasoned with. I'll give you a fifteen-minute extension. But I'm telling you-if you don't finish in an hour and fortyfive minutes... [deliberately cuts the sentence]

KASAMA What will happen, sir?

SEÑOR You'll see. 
Scene Four

I Need a New Deadline

SEÑOR You know you only have a minute left.

KASAMA I've chopped three bamboo. There were so many hornets in the trees.

SEÑOR Forty-five seconds...

KASAMA Sir, I still need three more, so that the raft isn't too narrow. And we need supports in the middle and on both sides-I'm planning to split one bamboo into three for this. That makes four, right sir? Well what do we use to row? Sir, it seems like we need to chop five more bamboo. I have one hour and forty-five minutes for three bamboo. That makes it thirty-five minutes for each one. We need five. If I add it up, let's see...[marks in the dirt to aid in his computation] I need three more hours.

SEÑOR Two hours and fifty-five minutes, idiot! Even with math, you'll take advantage of me.

KASAMA Sir, I just gave myself a tiny bit of allowance.

SEÑOR Who gave you the fucking right? Start tying the wood together. If you don't finish in half an hour... [deliberately cuts the sentence]

KASAMA What will happen, sir?

SEÑOR Oh, you'll see when the time comes. Half an hour, ha! I'm going to take a nap because I'm so fucking tired of waiting. 
Scene Five

What The Landlord Really Feels

SEÑOR I'm running out of patience! How are we not going to take forever? He's a lazy shameless fool! He's like a... chisel, you know? If you don't hammer it, it won't cut... He keeps making excuses, he has no imagination. How are people like that ever going to lift themselves? It's so hard, mind you, I have to weigh myself against this animal. If I don't, I might be killed. I don't know this place. What if he's waiting for an accomplice, which is why he's delaying me on purpose? What if he's spotted the money I have with me? I need to be extra careful! I didn't even try to nap. I just said that to see if he has an ulterior motive. I gave him some extra time but I advanced my watch. So he has little time left. The monkey is clever, as they say, but you can monkey with him in the end!

\section{Scene Six}

What the Tenant Really Feels

KASAMA [after placing the raft aside] Poor son of Don Fulgenciohe has no tolerance for hardship! He's not used in traveling by foot, especially under the burning sun-that's why he's all hot headed! I have got to finish this. Surely his needs are severe, that's why he's full of complaints. Honestly, I am not afraid of his threats. I didn't finish cutting the bamboos on time earlier but he didn't do a thing to me. He's all words. Once you get used to them, they enter one ear and go the other. 
God sees and knows all

You can do and take on

Even the impossible

If not how can one

Do anything at all

Or shoulder everything

Suffer the fullest

Do you think

It's easy to make it through

When there is drought

When there are floods

Where is the food?

Where is the hope?

Only God knows

Doesn't God find a way?

He doesn't doze off

Heaven, to us

Is oh so good

But the land has no mercy

But we can make it through

Though we may

Suffer the fullest

\section{Scene Seven}

The Reckoning

SEÑOR It's 4:10. Your time is up. No more extensions. This is the reckoning. 
KASAMA I've tied all the wood I can, but we're short on bamboo. The raft is too narrow, it will capsize. And we don't have anything to row with.

SEÑOR I'm a generous man. I'll give you one more minute to find something we can use to row. Go!

[KASAMA exits]

SEÑOR: [to himself] Thank God he doesn't have any ulterior motive. I gave him one more minute as thanks for being free from harm.

\section{Scene Eight}

\section{The Raft Is Ready to Launch}

KASAMA I can row with this staff. I loaded your bags already. I pushed the raft into the water.

SEÑOR Let's go! We've wasted too much time.

KASAMA But sir, I would not advise to use the raft. Let's just walk, it's all right if we go around far.

SEÑOR Are you out of your mind?! I've lost one whole afternoonand now you still want to waste time?

KASAMA The raft isn't steady!

SEÑOR Does it float?

KASAMA It floats, sir.

SEÑOR Then it floats! 
KASAMA Because we're not yet aboard, sir. When we go on it, when we reach the middle of the lake, if the waves get stronger-

SEÑOR I'll handle it.

KASAMA It's too dangerous!

SEÑOR I said I'll handle it! [Brings out a pistol.] Go, go! [To the audience.] If only I didn't need him until I get to the other side of the mountain, I really would have shot him by now. I'm going to die of exasperation! [To the KASAMA.] Go!

\section{Scene Nine}

\section{The Raft Has Gotten Far}

SEÑOR You see? We've reached the middle of the lake without any problem!

KASAMA [sings to the audience]

We should really learn to trust

The one who's educated

The vision's limited

Of the ignorant like me

If it's our bird-brain

We solely depend on

What will happen

To the life we have?

What will happen

To the life we have? 
Don't ever mistrust

The one who knows the science

If all one's ever had was the brain

Of the beast of burden

Where else will our fortune

Fall if not soaked

In the spoiling soup

Of pain and misery

In the spoiling soup

Of pain and misery

\section{Scene Ten}

The Raft Is Nearly Destroyed

[Thunder and lightning.]

SEÑR Why is the raft wobbling?

KASAMA The waves are getting bigger! The winds are getting stronger! There's a storm coming!

SEÑOR Row faster so that we won't get caught in it mid-sea!

KASAMA The wood is creaking! The vines are coming loose! The raft is coming apart!

SEÑOR Do something, you animal!

KASAMA We're too heavy. Let's throw your bags overboard so that we get lighter!

SEÑOR Have you lost your mind? My stuff is in there! We're near the bank anyway, jump into the water and swim! 
KASAMA The waves are too harsh, how will I get to shore?

SEÑOR You're a good swimmer, aren't you?

KASAMA Yeah, I can swim, but my body can't take it now. I'm exhausted from what I had to do earlier. What are the chances I'll make it to shore alive?

SEÑOR A greater chance than if I shoot you to save myself!

KASAMA Sir, if only my body can-

SEÑOR The Lord has mercy, He will not forsake you! Just think that you are putting your life on the line for my own good. (You'll be inspired and your body will be reinvigorated! And don't worry, while I'm rowing to shore, I'll pray for your success!) [Spurns the KASAMA, who will scream as he falls into the water.]

\section{Scene Eleven}

\section{The Tenant is Free From Harm}

[On the other side of the lake.]

SEÑOR Where is that animal! I've been waiting and waiting! It's dark. There might be bandits around here. That imbecile is putting me in danger!

[The KASAMA appears, out of breath and limping.]

SEÑOR Why did you only get here now! I've been worrying about you! 
KASAMA The Lord loves me, and continues to bless me! I thought I was out of strength, but I was able fight through the waves. Something struck the back of my neck and I lost consciousness. When I woke up, I was on the shore, the storm subsided. Thank you, dear sir, for your prayers! I may be weak, hungry, and my ankles hurt a little but here I am, safe and sound!

[The actors will sing in praise to two very important qualities of people: Perseverance and Willpower.]

When you want something

Make yourself strong

Do not be afraid

If it all goes wrong

As long as you're not scared

And you persevere

Wherever you will go

You will not falter

You'll always get your way

If you have the will

You'll only ever fail

If you're stupid and full of fear

Always remember this:

You hold in your hand

The fate you will have

It's all up to you 
Scene Twelve

Dialogue About the Division of Food

SEÑOR We need to save food. If not, we won't have anything for tomorrow. Our ration today is...four pieces of lemon bread and three slices of cheese. The division needs to be fair.

KASAMA That's easy, sir! We each get two slices of bread and one slice of cheese, and then let's split the last slice into two equal halves.

SEÑOR Is that fair?

KASAMA According to the principle of arithmetic that I learned in grade one, sir.

SEÑOR But should the principle of arithmetic be used in this situation?

KASAMA Shouldn't it, sir?

SEÑOR We are facing a moral situation. There's a far greater principle that covers these kinds of situation.

KASAMA What, sir?

SEÑOR The principle of SOCIAL JUSTICE.

KASAMA What a nice name!

SEÑOR Let me explain... According to the principle of social justice, the distribution of life's comforts needs to be fair/ just. And it is only fair/just when each person receives what is apt, I repeat, what is apt to their own needs. Thus, everyone's comfort is equal, not because what they strive for is equal, but in the end, the happiness they feel is equal. 
KASAMA What a great principle...

SEÑOR Now...it is clear everybody has different needs. Someone with long limbs, needs a larger mosquito net. Someone who easily gets cold needs a thicker blanket. Someone with crippled legs needs a cane to walk properly. Here... I got you a walking stick. I don't need it because nothing is wrong with my legs. You're the one limping, which is why it is only fair for me to offer you the walking stick [offers the stick]. Is that example clear?

KASAMA Crystal, sir. What a great example!

SEÑR Now, let's discuss the question about the four pieces of bread and three slices of cheese. I'll test you again.

KASAMA Sure, sir, so that I will learn.

SEÑOR Are you used to physical hardship?

KASAMA Naku, yes sir.

SENOR Why is that?

KASAMA Oh, that's a given when you're poor. When did we ever have a taste of ease?

SEÑR Very good! Therefore, you usually run out of food?

KASAMA Naturally, sir. As long as there's drought, storms, or floods, or if the locusts devour our crops, then we're low on rice, the vegetables are rotten, the fish in the streams drift to wherever, and even salt is as expensive as gold. We are lucky if we can have a taste of food once a day. And that is not unlikely to happen, sir!

SEÑOR Your observation is very good! But how do you survive? 
KASAMA By the mercy of God! Even if we run out of food, even if we lack sleep and rest, look at us-still as strong as a boar!

SEÑOR You poor people are really amazing. On the other hand... there are people like me. In your opinion, am I used to fate being cruel to me?

KASAMA You? Naku, of course not, sir!

SEÑR Why do you say that?

KASAMA E how would you get used to that, when you are surely rich in everything?

SEÑOR You have a very sharp mind-you should have been a scholar!

KASAMA I just got lucky, sir.

SEÑOR Then let's see... According to the principle of fairness that I outlined to you earlier, how would you divide the four pieces of bread and three slices of cheese. Be careful. Consider what I asked, and what you answered...

KASAMA That's easy, sir. You're used to being full, I'm used to being hungry. Your needs are twice as much compared to mine. In this situation, three pieces of bread is to one piece bread; two slices of cheese is to one slice of cheese. Is that right, sir?

SEÑOR Your intellect is outstanding! Just one thing...you're forgetting one thing.

KASAMA Is that so?

SEÑOR Okay, think about it.

KASAMA [thinks hard] 
SEÑOR

KASAMA I don't get it, sir. My brain is not used to challenges like this. That's why I didn't finish grade school.

SEÑOR

KASAMA

SEÑOR

KASAMA Oh, forgive me, sir! In my ignorance, I did not consider

SEÑOR

KASAMA

SEÑOR

KASAMA

SEÑOR that. I have no right to the food you brought.

You give up?

I give up, sir.

Think about this. Who brought the bread and cheese? In fact, who bought the bread and cheese? Who is the true and sole owner of the bread and cheese?

Your deduction is spot-on.

You can have it all, sir. I'm not that hungry anyway!

Tsk, tsk, tsk... that's not what I wanted to say. I need to give you something.

But that will go against the principle of SOCIAL JUSTICE!

Yes, and no. Because there is an even greater principle in the life of society-the Law of Generosity-what the theologians refer to as Charity-the most beautiful trait that can live in the heart of man! How could I even bear to eat and eat in front of you, while you just stare and watch me chew? If the rich do not take care of the poor, wouldn't that be disgusting? Yes, it is our responsibility, I repeat, our responsibility to open our hearts to the likes of you. It is said in Scripture, "Again I say to you, it is easier for a camel to go through the eye of a needle, than for a rich man to enter the kingdom of God." So accept these alms...half 
a piece of lemon bread. Take it, and if you wish to reward my kindness, pray for me to St. Peter.

KASAMA [reaches for the bread] To St. Peter, St. Joachim, St. Isidore, St. Martin, and St. Barbara, the patron saint of my late mother!

[eats the bread as if extremely hungry]

SEÑOR A favor please! Take it easy when you eat your bread. I don't want your food to be finished while I'm not even halfway! [Actors sing about Social Justice]

The world order Is based on one Primary rule Social Justice

All you lords and ladies Just make sure That your Social Justice Isn't false justice

When there's danger

Look to the rich

How will you be refused

By Social Justice

All you lords and ladies, etc.

Those without rights

Won't be ignored

So that they can put in place

Social Justice 
All you lords and ladies, etc.

The poor have the upper hand

They won't be in the cross-hair

When it is compromised,

Social Justice

All you lords and ladies, etc.

Scene Thirteen

We Must Avoid the Bandits

[The two are sleeping under the tree.]

SEÑOR [suddenly wakes up] Wake up! Something's rustling in the bushes!

KASAMA Probably birds, or lizards.

SEÑOR Can you be sure they're not bandits spying on us?

KASAMA It might be bandits.

SEÑOR Aren't you scared?

KASAMA They're easy to talk to.

SEÑR If they slit your throat, how will you talk to them?

KASAMA They don't kill people just like that. More often than not, they stand up for the oppressed against the oppressors.

SEÑR It seems like you're friends with them. Tell me the truth. 


\begin{tabular}{|c|c|}
\hline KASAMA & I know some of them. Don't worry. \\
\hline SEÑOR & You brought me here to betray me, haven't you? \\
\hline KASAMA & No sir! \\
\hline SEÑOR & Prove your loyalty to me. \\
\hline KASAMA & Okay sir. \\
\hline SEÑOR & [waits] \\
\hline KASAMA & [waits] \\
\hline SEÑOR & $\mathrm{O} ?$ \\
\hline KASAMA & O what, sir? \\
\hline SEÑOR & Where's your proof? \\
\hline KASAMA & Aren't my words enough? \\
\hline SEÑOR & Are you fucking stupid? What use are your words to me? \\
\hline KASAMA & What would you like me to do, sir? \\
\hline SEÑOR & $\begin{array}{l}\text { Like this... let's exchange clothes. So that when they get us, } \\
\text { you'll be the target. }\end{array}$ \\
\hline KASAMA & Yes sir. \\
\hline SEÑOR & $\begin{array}{l}\text { If they're easy to talk to, you have nothing to worry about, } \\
\text { right? }\end{array}$ \\
\hline KASAMA & Yes sir. \\
\hline SEÑOR & And then I'll be at peace. \\
\hline KASAMA & Yes sir. \\
\hline SEÑOR & You agree? \\
\hline
\end{tabular}


KASAMA Yes sir.

SEÑOR Yes sir?

KASAMA Yes sir, sir. I'll clean up our mess. [exit]

SEÑOR [to the audience] That animal is playing with me! He didn't even hesitate. Now I'm even more suspicious. Would anyone in his right mind be so gullible?

[Sings.]

Steer clear of people

Who always say yes

Don't be so sure

They're on your side

When he says yes

Be vigilant

If you're not wary

You'll be caught off-guard

Is there a fellow

Who'll let himself be fooled

If he hasn't talked to the devil

To be bait for you

Look closely and ask why

He acts like a fool

Watch him bare is fangs

The idiot is a snake

Life is so hard

When you're a landlord

Such great danger 
You'll surely encounter

Scene Fourteen

The Disguising of the Landlord and Tenant

[IMPROVISED SCENE. The landlord wears the tenant's jacket, which is a little tight and very smelly. The tenant wears the landlord's coat, which is a little loose and smells good. The landlord teaches the tenant to fix his posture, as if he were rich. The tenant is scared and nervous with pulling off the disguise.]

[One sequence of dialogue missing or excised in the translation]

SEÑOR Just take a deep breath. Your breathing has to be relaxed. Hold your head up high. And stand your ground. You're not unlike a giant of legend that makes the mountains quake and the rivers and seas tremble when you place your mighty footstep on the earth.

KASAMA Other people...won't they be jealous of me? Won't they resent me?

SEÑOR Be proud if you want to be looked up to! Be firm if you want to be worshipped!

KASAMA But Heaven, sir, Heaven! The angels in heaven will be appalled. They might punish me because of my excessiveness.

SEÑOR In the name of the entire hierarchy of heaven, I tell you there is nothing to worry about.

KASAMA Is that true?

SEÑOR They're easy to talk to. 
KASAMA If you're being struck with burning daggers and being sent to the very depths of hell, how will you talk to them?

SEÑOR They won't forsake you just like that. Actually, they stand up for whoever has something to say/influence.

KASAMA It seems like you're close to them, sir!

SEÑOR Of course! The masses and processions I offer up are non-stop. I memorize fourteen different novenas! I've read the lives of all the saints on the calendar! If only girls didn't love me so much, I would have been a monk and put up my own church!

KASAMA Good heavens!

[Actors will sing about the utility of Power.]

You cannot estimate

The extent of their power

It is such a mystery

The virtue that they hold

When there's money and a name

And an inherited brain

It's like a jeepney you can't stop

When it's revved up and running

Only the law of the jungle

Rules over everything

What is Right and Wrong

Is one and the same 
Scene Fifteen

The Miracle of the Lemon Bread

SEÑOR Stop first, I'm hungry again.

KASAMA But you just ate.

SEÑOR That's why I'm hungry again. When the stomach is awakened, you get hungrier. That's the law of nature!

KASAMA Those that must endure, while suffering can endure more. Which is good, because the Pit of Grief is bottomless.

SEÑOR What is the opposite?

KASAMA The wealthy can never get enough wealth.

SEÑOR For example?

KASAMA Those who are educated need to study further. Those who own a lot need to gain more. Those with power need to expand their empires.

SEÑOR You now know life's most important principle. There, you'll find the key to Changing the World-the Matrix of Human Civilization!

KASAMA I understand everything! It's like there's something that sparked my consciousness... and suddenly...I saw a glimpse of the Meaning of All Life...the Mystery of Fate...the Knowledge of Universal Light! How many pieces of bread do we have left?

SEÑOR Ten. I'll eat two now. Eight will be left for tonight and tomorrow morning.

KASAMA [in a different tone] Eat what you will! Just leave one! 
SEÑOR What? I'll die of hunger!

KASAMA Que Tonteria! Give me the bread!

SEÑOR What will you do with it?

KASAMA Just give it to me! [The landlord is forced to give the bag of bread. The tenant will throw all the bread except for one. The landlord is stunned.] Watch! Look at this piece of lemon bread. I will multiply it! Don't blink or you'll miss the miracle I'm about to perform! [The tenant closes his eyes and offers the bread to the universe. There's a mysterious ritual performed. After a while, he opens his eyes.] Why did nothing happen?

SEÑOR I don't know with you!

Scene Sixteen

The Bandits Arrive

[They hear the galloping of horses.]

SEÑR The ground is shaking.

KASAMA The steps of my mighty feet.

SEÑOR No-horses! One... two... three... Let's hide!

KASAMA Hide if you want to! I will face them.

SEÑR Are you sure you can take them?

KASAMA You'll see! 
[The landlord hides. THREE BANDITS arrive, armed and on horseback.]

BANDIT ONE [to the tenant] Partner, it seems like you're lost in our territory. Is there something we can do for you?

KASAMA Well, it's like this...I need to reach the other side of the mountain as soon as possible.

BANDIT TWO We'll take you on horseback.

KASAMA Just show me the way.

BANDIT THREE It's far, my friend. It looks like you're not used to walking under the sun.

KASAMA Esta bien.

[The tenant gets on the horse. The landlord shows himself.]

SEÑR Friends, bring me with you!

BANDIT ONE Don't be so ambitious! With how you look, you're more fit to walk and crawl!

\section{SCENE 17}

The Landlord's Regret

SEÑOR [to the audience] Why did I ever exchange clothes with that idiot? I didn't realize the bandits here are such kind people. They know how to respect people who wear good clothes. What a shame! So I had to walk all afternoon. I didn't get lost though because I followed the horse's hoof 
prints. But I'm dead tired and dying of hunger. I tried eating a guava that I picked from a tree along the way, and my stomach grumbled right away. Sensitive stomach, with a lining as thin as silk. What a hard life this is!

(Sung to the audience)

Don't be scared of bandits

People good and kind

Dress well even if you look

A fool, you're a saint in their book

Drum this into your head:

If you're poor like me

And in desperate need

Who will save you when you bleed?

That's why, my friends

Keep your pockets full

So you won't have much to worry

When trouble comes in a hurry.

God may bear

The hands of fate

Just be sure, when tomorrow comes

You have always the upper hand 
Scene 18

What the Landlord Saw When He Reached the Plain

[The tenant is sprawled on the ground.]

SEÑOR Hey, what's this? Where's my suit? [Kicks the tenant.] Hey, are you asleep?

[Open's the tenant's eyelids wide.] Are you dead, you fool? [Hears someone approaching.] The bandits! And one of them is wearing my suit! [The three bandits enter, mounted on horses].

BANDIT ONE Killed him because he made a fool of us.

BANDIT TWO Questioned him, then brought him here on the plain.

BANDIT THREE A well-dressed man, but no money.

BANDIT ONE Isn't that enough to kill someone?

BANDIT TWO It's a mortal sin to pretend you're someone else.

BANDIT THREE You lose your trust in other people.

SEÑOR In that case, I'll be honest with you. That man is only a tenant in our land. I am the true landowner. I only changed clothes with him because...well...

BANDIT ONE Your kindness is admirable!

BANDIT TWO Your kindness must be rewarded.

BANDIT THREE Your kindness must serve as an example to others.

BANDIT ONE May we ask you some questions?

BANDIT TWO To smoothen our relationship even more. 
BANDIT THREE To foster dialogue among us.

SEÑOR All right, my friends. My life is an open book.

BANDIT ONE Did this tenant freely and willingly accompany you to the mountains?

BANDIT TWO Think well before you answer.

BANDIT THREE Be up front with us, you hear?

SEÑOR I will be up front with you. Please repeat the question.

BANDIT ONE I will repeat the question. Did this tenant freely and willingly accompany you to the mountains?

BANDIT TWO Did he freely and willingly serve you?

BANDIT THREE Did he freely and willingly exchange clothes with you?

SEÑOR Well...Let's just say that he did not get a chance to say no.

BANDIT ONE Because you held him by the throat.

BANDIT TWO Because you have the power to pin him down.

BANDIT THREE Because he will always say yes to anyone whose position is higher than his own.

SEÑOR That's the way it is.

BANDIT ONE That's the law of nature.

BANDIT TWO A chicken is no match for an eagle.

BANDIT THREE The survival of the fittest.

SEÑOR I believe we understand each other in many matters of life. 
BANDIT ONE But wait, sir... Do you have any proof to show that you are what you say you are?

SEÑOR Aren't my words enough?

BANDIT ONE Papers are needed.

SEÑR What kind of papers?

BANDIT TWO Just papers, no need to elaborate.

SEÑOR Papers, huh? [Will remove his money belt.] There! Have all the papers you want! [Throws the money on the ground.]

BANDIT ONE [Picks up the money and examines them.] You are truly a noble person!

BANDIT TWO Noble and Honest.

BANDIT THREE Honest and Reliable.

SEÑOR Thank you, my friends.

BANDIT ONE But we still have to kill you.

SEÑOR But why is that?

BANDIT TWO Because you take advantage of people who are beneath you.

SEÑOR But you yourselves said that this is the law of nature.

BANDIT THREE We were just leading you on.

SEÑOR Well, look at it this way, can I buy my freedom for a thousand dollars? 
BANDIT ONE Well, look at it this way, your life is in our hands, your money is in our pockets.

BANDIT TWO What then can you sell?

BANDIT THREE Yes, what then can you sell?

BANDIT ONE You have nothing to sell, nothing!

BANDIT TWO You have nothing to bargain with, nothing!

BANDIT THREE You have nothing to count on, Mister Zero.

SEÑOR [Drawing out his gun.] But I do, my friends. And don't reach out for your weapons. Now give me my money!

[Bandit One will throw the money on the ground. When the landlord bends down to pick up the money, the three bandits pounce on him. They kick him until the landlord lies prostrate on the ground.]

BANDIT ONE You see, sir? This is the real fight-not the rich against the poor, not the wise against the ignorant. That's cheating! The strong versus the strong, that's the proper kind of fight! Skill against skill!

BANDIT TWO The eagle may devour a chicken, but the python will gobble the eagle!

BANDIT THREE And that sums up the law of nature!

SEÑOR In that case, who has the real power?

BANDIT ONE God, sir, God!

BANDIT TWO Even us three, we surrender to God!

BANDIT THREE For on Judgment Day, what good is our strength, our skills, and our weapons? 
BANDIT ONE Sir, get ready, the hour is near.

BANDIT TWO Sir, sharpen your eyes and gaze at the clouds.

BANDIT THREE Sir, closely watch the vastness of the sky and start to tremble.

SEÑOR [falls into a kneeling position while watching the heavens] I see a reflection of something which looks like wings.

BANDIT ONE The Archangel of Judgment Day!

BANDIT TWO Sir, cock your ears and listen to the music of the heavens!

SEÑOR [closing his eyes] I hear a swooshing sound.

BANDIT THREE The flapping of His Holy Wings!

[The three bandits sing.]

When down he comes

the Archangel on Judgment Day

What will happen then

Peace and good will to all men.

When down he comes

The Archangel on Judgment Day

Sinners all the way

A heavy price they'll pay

When down he comes

The Archangel on Judgment Day

Everyone will know

Nature's secret high and low 
[The sound of an approaching helicopter is heard. A machine gun fires from above. The three bandits fall to the ground. A rope ladder descends from above. The landlord rises. He will pick up his stuff and climb up the ladder, and will head towards the heavens.]

The final song of the actors:

In art the opposite

Of reason can be true

So never emulate

A logic so hollow

Our way of life

Ought to be changed

We must turn our back

To our exploitative ways

Wealth that comes

From cheating must go

Wisdom instead must be

Knowledge pure and holy

What the country needs

New rules, new ways

A new social order

A new covenant, no other

The educated among you

Who judge all things

Can you find the discipline

To change your skin? 
Can you manage

To forego luxury

So you do not swim like fish

In a life so smug and selfish

Can you forsake

Even for a while

The worship of gold

Can you put it on hold?

Can we align

Our thoughts and our deeds

And make Utopia a living dream

Not theory, or thesis, or monograph

For reading, only fit for kindling

Or to wrap a sandwich in

For the annoying truth

Is like an aching tooth

We are so full only of ourselves

Up to our neck in each other

-End- 


\section{Works Cited}

Eco, Umberto. Experiences in Translation. University of Toronto Press, 2001.

Paloposki, Outi \& Kaisa, Koskinen. Handbook of Translation Studies (vol. 2). John Benjamins Publishing Company, 2009.

Venuti, Lawrence. The Translator's Invisibility. Routledge, 1995. 